\title{
Zofia Ziemann* \\ Translator Profile in the Discourse around Translation: Promotion and Reception of the English Translations of the Fiction of Bruno Schulz
}

\begin{abstract}
The paper discusses the role of (perceived) translator profile in the current promotion and reception of three competing English translations of fiction by the modernist Polish-Jewish author Bruno Schulz (1892-1942): Celina Wieniewska's 1963/1978 canonical version, John Curran Davis's ca. 2005-2010 online fan retranslation, and Madeline Levine's retranslation, publicized since 2012 and forthcoming in 2018. Based on a para- and extratextual analysis of the discourse around these versions, combined with archive research into translator history, it explores the ways in which the translator's profile is used to promote the translation and develop or support opinions about it. Wieniewska's personal background, difficult to access due to the invisibility of the 'historical' translator, has been ignored by readers and critics, even though it would help understand her choice of translation strategy and thus make the recent criticism of her translation more informed. Conversely, in the case of Davis and Levine, not only are the retranslators visible to the extent that they actively promote their work themselves, but also judgments are passed, boundaries drawn and distinctions made based on their profiles rather than their performance: their work has been assessed to a large extent without reference to their actual translation choices. The retranslators' lives - educational background, affiliation, professional experience - all turn out to play a major role in the critical discourse around their work, replacing the reading or, in the extreme case of Levine's yet unpublished translation, even the very existence of the translated text.
\end{abstract}

\section{Keywords}

literary translation; translation reception; translation promotion; translator's profile; retranslation; non-professional translation; publishing market

This paper presents the results of research funded by the Polish National Science Centre under PRELUDIUM research grant no. 2014/15/N/HS2/03913.

\section{Preliminary Remarks}

Re-examining the famous map of Translation Studies to accommodate for the emerging discipline of Translator Studies, Andrew Chesterman discussed the positioning of research on translators in relation to particular sections of Holmes's model, eventually proposing his own new map (Chesterman 2009). As regards Holmes's applied branch, apart from the self-evident connection between Translator Studies and translator training, Chesterman commented on the relevance of translation policy and translation aids to the new subfield of the discipline. Of the "last sub-type, translation criticism", he only wrote that it "does not seem to lie within Translator Studies" (Chesterman 2009: 18). Indeed, it is beyond question that neither translation criticism in the Holmesian sense of an applied branch of TS nor translation reception as an object of research in descriptive studies, e.g. translation histories, "lie within" Translator Studies. However, this does not mean that they are not relevant to problems raised by scholars working in the subdiscipline. In what follows, I would like to propose an example of how research on flesh-and-blood translators and research on the critical reception of their work can be brought together.

* Zofia Ziemann

Jagiellonian University, Kraków, Poland

zofia.ziemann@uj.edu.pl 


\subsection{Subject, Scope and Methodology}

This paper takes a critical look at present-day discourse around translated literature, both at the giving and receiving end, i.e. promotion and reception, from the point of view of one of the central problems of Translation and Translator Studies: the translator's (in)visibility - not in the sense of the translator's discursive presence 'in' the translated text (Venuti 1995: 1), however, but in the more 'extradiegetic' sense of his or her presence 'around' the text. To refer to Kaisa Koskinen's tripartite categorization proposed in the context of translation ethics, I will be interested in "para-" and "extratextual" rather than "textual visibility" (2000: 98-103), with a view to understanding how, to what extent and to what effect the translator's profile features in the promotion and influences the reception of his or her work. Does it help a translator to be seen? In the case of competing versions of the same text, how, if at all, are the translators' profiles used to draw boundaries and make comparisons between their translations? Is this reflected in the reception? Does knowledge of the translator's profile always make the discourse surrounding a translation more informed?

These questions will be asked with respect to limited material: three English translations of the fiction of the Polish-Jewish modernist author Bruno Schulz (1892-1942). Although created decades apart, Celina Wieniewska's early canonical version dating from the 1960 s and two $21^{\text {st }}$ century retranslations by John Curran Davis and Madeline Levine currently coexist and compete. The work (in the sense of both product and activity) of these three translators has constituted the focus of my PhD research on the texts and contexts of the English translations of Schulz's fiction, from 1958 to the present, which combines a diachronic and synchronic perspective. Here, I will concentrate on the contextual and synchronic aspect, and I will discuss only the authors of booklength translations, disregarding the translators of individual stories, essays and letters dispersed in anthologies and magazines, since, given their limited impact, they are relatively unimportant for the history of Schulz's presence in the anglophone world (in this practical criterion for data selection, I follow Pym's view of 'importance' in translation history research; 1998: 20-36).

My methodological approach has been determined by the chronological span of the material. With respect to the early translator, of whom very little had been known prior to my project, I conducted extensive archive research, reconstructing her biography, views and attitudes based on personal papers recovered from a number of museum and library collections in Poland (for constructing historical translator profiles using archive material, see Munday 2014). With respect to the two retranslators, I have relied mainly on online sources (interviews, articles, blogs, social media profiles). I have also contacted the retranslators and other stakeholders (the copyright holder, the commissioner of Levine's retranslation, scholars, critics) to gain insight into the context of the production of their translations.

Discourses surrounding the translations in question have been analysed based on para- and extratexts as defined by Gerard Genette (1997) with reference to non-translated literature, and subsequently adopted for TS (see Tahir Gürçağlar 2011). The former category encompasses peritexts, i.e. texts and visual material directly framing a published translation (cover, title, preface, notes etc.), and, more importantly for the purposes of this paper, epitexts, i.e. authorial/translatorial texts concerning the translated text proper, which, if known to the reader, can influence its reception but function outside (e.g. interviews, letters, diaries). The latter include reviews and critical discussions written by third parties, beyond the control of the author, translator or publisher. As Sharon Deane-Cox has observed, "extratextual sources of information on (re)translation such as reviews ... are often, and erroneously, discussed in Translation Studies under the heading" [of paratext - Z.Z.]" (2014: 30). I would hesitate to call such an approach downright erroneous; rather, I see the merging of para- and extratext as a terminological 'shortcut' (admittedly risky, if one references Genette without making this convergence explicit), operative to the extent that it reflects the similar role these two categories play in translation research; after all, they both constitute an invaluable source of information on the functioning of the translated text in its context - this might be why the distinction originally made by Genette is so often ignored. 
Arguably, in the digital age also the distinction between epi- and peritext, made by Genette according to the 'spatial' criterion (Deane-Cox 2014: 26), does not seem to hold very well: in online publications, hyperlinked material does not exactly belong to the 'volume' but it is accessible at one click of the mouse, and so it cannot be considered to be fully 'external' either. In what follows, my main criterion for inclusion of research material was relevance: I have taken into account all sources, whether para- or extratextual, which I found to reveal something about the circulation of Schulz translations, i.e. the ways in which they present themselves and are presented to the reader. This is in fact in line with the approach of the originator of the concept of paratext, who, despite offering a detailed typology, noted that "in principle, every context serves as a paratext" (Genette 1997: 8).

Being limited in scope, qualitative and material-oriented rather than problem-oriented (see Olohan/Baker 2009: 147), my research describes an example of a certain phenomenon and has no pretence to constitute a representative case study (see Susam-Sarajeva 2009). However, thanks to the nature of the analysed material, it is, I believe, informative in the sense that it brings into sharp relief different, and indeed opposing, forms of the relationship between translator visibility on the one hand and translation promotion and reception on the other, problematizing the positive axiology conventionally and uncritically accorded to the phenomenon of translator visibility, and it is replicable to the extent that it invites other researchers to pay attention to this relationship when dealing with other types of material and/or larger data sets.

\subsection{Definitions}

Two terms used in the title of this paper need clarification. By translator profile I mean the sum of information about the translator - from personal details such as age, gender and nationality/ ethnicity to work-related information such as educational background or professional experience - which may be available to the public and circulate in the discourse around his or her translation. This unspecialized term is adequate, I believe, in that its very etymology emphasizes the semantic aspect most relevant for my discussion: something is profiled 'against' a background, i.e. it stands out, it is visible. As understood here, translator profile is perceived and public, as opposed to the translator's identity, which I understand as authentic, intrinsic and private. In this respect, profile is similar to the notion of persona, which, as introduced by Sela-Sheffy (2008), refers specifically to self-representations of high-profile translators in the media. I deliberately avoid the fashionable if problematic habitus, which, although relevant, should arguably be reserved for studies explicitly dealing with (post)Bourdiesian sociology of translation; my research, informed as it is by sociological questions, does not make direct use of this theoretical framework (for a discussion of habitus and identity, see Sela-Sheffy 2014). Another related term, translator status, has to do with social recognition, power and prestige, and recently has come to be associated with the position of the translation profession in general or certain groups within that profession rather than that of the individual translator (e.g. Sela-Sheffy/Schlesinger 2011, see also Dam/Koskinen 2016). In the case of individuals, status to a considerable extent results from the translator's profile. As for translator visibility, it was already indicated in the previous section that it is here understood as the inclusion of the translator's profile in the discourse surrounding his or her work.

Discourse around translation is used in this paper as an umbrella term covering the para- and extratexts, regardless of authorship (i.e. whether written by publishers, reviewers, literary critics or lay readers), related to the promotion and reception of the translated text. The choice of such a broad notion was determined by the material: as will be seen below, in the case of Schulz's retranslators we cannot speak of any specific publishing strategies of promotion or marketing, because there are no publishers involved, and the retranslations are discussed largely on the Internet, not by professional reviewers but by ordinary readers and other interested parties, e.g. Schulz scholars. Hence the need for a term broader than translation reviewing and/or criticism (see Maier 2009, Paloposki 2012), reserved for professionalized, usually journalistic practices concerning the circulation of translated literature. Translation quality assessment, on the other hand, is felt 
to be inadequate in that it is associated predominantly with various models of text analysis, while my chief interest here is context; moreover, TQA has grown to be associated mainly with non-literary translation and translation training.

\subsection{Theoretical Background and Literature Review}

Unsurprisingly, my research is informed by the long tradition of discussions of the translator's invisibility in the anglophone literary world on the one hand and studies in translation reception, in particular in the context of retranslation, on the other; within the confines of this paper, I will only be able to indicate selected references. The very origins of the concept of translator invisibility lie in an analysis of discourses around translation in a historical perspective. Lawrence Venuti's seminal The Translator's Invisibility (1995) and The Scandals of Translation (1998) both feature critical discussions of translation reception. More recently, Venuti (2013a [2004]: 100-101) also foregrounded the specifics of the retranslator's agency, arguing that the retranslator's intentions often play a more pronounced role in originating the retranslation than the first translator's in originating his/her work. Logically, it seems to follow - although Venuti does not elaborate on this aspect - that the retranslator should be more visible than the previous translator, both in and outside the retranslated text.

Studies on retranslation, especially in the diachronic perspective, offer comprehensive discussions linking the concept of translator invisibility with discourses around translations. Following Paloposki's and Koskinen's (2004) eye-opening critique of the retranslation hypothesis, scholars working in this area not only reconstruct but also critically engage with translation norms dominant at a given time, in order to demonstrate the contingency of translation assessment on a particular moment in the history of the target culture. What is important is that they often go beyond the determinism of the 'translation-as-a-product-of-its-time' approach, focusing also on the individual agency and cultural, social or political agendas of the early translators. Recent examples of such research include book-length studies on English retranslations of European classics - Mann (Horton 2013, see also Hermans 1999: 1-6, Venuti 2013a [2004]: 97-98), Flaubert and Sand (Deane-Cox 2014), and Kafka (Woods 2014).

It seems that more recent, let alone present-day discourses around translation have received considerably less attention than their historical variety, perhaps due to the lack of temporary distance which many researchers feel to be necessary to guarantee a degree of critical detachment and objectivity. Exceptions include papers by Peter Fawcett (2000) - a study of a small corpus of 1990s press reviews of literature translated into English - or Isabelle Vanderschelden (2000a, see also Vanderschelden 2000b) - an analysis of evaluation criteria for literature translated into French - as well as Venuti's more recent confrontations with critics, including those who rejected his own translations (2013b [2011]).

As Kaisa Koskinen has pointed out, the concept of translator visibility not only "acquired general acceptance" (2000: 99) as a theoretical category, but has been seen in positive axiological terms. Similarly to sociologically oriented research on the translation profession informed by an ethical agenda, whether explicit or implicit, aimed at ultimately raising the status of translators by pointing out their currently undervalued position, studies addressing the problem of the invisibility of the literary translator seem to share the presupposition that visibility is a positive value and should be strived for. There seems to be a consensus that early translators should be brought out of the shadows so that justice is done to their now-criticized work or that contemporary translators should play an important role in the promotion of their work and should be acknowledged in reviews. Much as I agree with this ethical stance, in this paper I would like to discuss an example of translator visibility which slightly complicates matters, suggesting that just as "increased visibility [of the translator in the paratext - Z.Z.] is not an automatic guarantee of an explicit and transparent translation process" (Koskinen 2000: 103), including the translator's profile in discussions of his or her work does not by definition guarantee a fair and informed treatment. 


\section{Bruno Schulz in English: An Overview of Translation and Publishing History}

Bruno Schulz, visual artist and writer canonical in Polish literature, is one of relatively few $20^{\text {th }}$ century fiction authors working in that language who have also attracted international readership. In the 1930s, he published two volumes of short stories ${ }^{1}$ - oneiric tales of a provincial town strongly resembling his native Drohobych (in present-day western Ukraine), where reality merges with fantasy. They are told in a rich, sensuous, exquisitely stylized prose by a young first-person narrator, the author's alter ego (see Ficowski 2003). Despite the scarcity of his output, Schulz's posthumous international career has successfully developed since the appearance of first translations in the late 1950s, and today his works are available in more than thirty languages, in eight scripts. ${ }^{2}$

\subsection{The Ambassador: Celina Wieniewska}

Initial attempts at introducing Bruno Schulz's work into the anglophone world failed: in late 1940s, a book-length translation of his stories was rejected by an American publisher ${ }^{3}$, and the several stories that appeared in rather obscure anthologies and a magazine at the turn of the 1950s and 1960s received no attention whatsoever. It was only in 1963, almost thirty years after its Polish premiere, that the first volume of Schulz's stories was published in English, translated by Celina Wieniewska (1909-1985), a Polish-Jewish émigré translator, editor and publishing representative based in London. Given the reluctance of anglophone publishers towards translated literature, especially from lesser-known languages, it is noteworthy that Wieniewska's Schulz was published on both sides of the Atlantic: in the UK as Cinnamon Shops (a literal rendering of Sklepy cynamonowe, the Polish title of the collection and one of its stories; Schulz 1963a) and in the US as The Street of Crocodiles (the title of another story in the volume; Schulz 1963b). However, despite favourable to enthusiastic reviews in the British and American press (including The Times Literary Supplement, The Spectator, The Guardian, The New Yorker, The Herald Tribune), Schulz remained largely unknown to the anglophone reader until 1977, when Philip Roth reissued The Street of Crocodiles in his influential Penguin series "Writers from the Other Europe" (alongside Milan Kundera and other authors from beyond the Iron Curtain). The publication of the second volume, Sanatorium under the Sign of the Hourglass, also translated by Wieniewska, followed shortly (Schulz 1978), accompanied by the appearance of stories from this collection in The New Yorker and The Partisan Review. Ever since then, Schulz has enjoyed a sustained and indeed steadily growing popularity in English-speaking countries. Subsequent editions of one or the other volume or collected works have been published with the average frequency of three years, complemented by numerous reprints of individual stories in various anthologies (e.g. Schulz 1998, Schulz 2011). ${ }^{4}$ Wieniewska's translation has also been symbolically canonized, be-

1 Evidence from his correspondence suggests that he also worked on a novel, Messiah, but the manuscript remains lost.

2 Apart from most European languages, including smaller ones like Catalan, Schulz's stories have been translated e.g. into Arabic, Hebrew, Chinese, Japanese, Korean, and Thai (see Stojanović [undated]).

3 In 1951, the Polish émigré writer Józef Wittlin mentioned this in a postscript to his letter to Witold Gombrowicz: "Some years ago I was asked by a large publishing house here [in New York - Z.Z.] to review the English translation of the stories of poor [reference to Schulz's tragic death at the hands of the Nazis - Z.Z.] Bruno Szulc [sic]. Even though the editor ... was enthusiastic, she was not able to overcome the commercially driven doubts of the owner of the publishing house. I offered to write an introduction, but I haven't been contacted since and the book has been lost somewhere." (Jarzębski 1996: 26; my translation).

4 It is worth noting that this long-lived version did not undergo any significant changes throughout its publishing history, hence my use of the phrase 'Wieniewska's translation' in the singular to refer to any edition of either one or both volumes of Schulz's stories as rendered by her into English. The original 1963 UK and US editions of the first volume Schulz's stories are identical save for the title; American English vocabulary (e.g. flat vs apartment, decal vs transfer for a mathematical operation) was introduced in Roth's 1977 edition, alongside minor changes in punctuation. Such variations are visible also in recent editions of both volumes; however, analysis shows that they most likely result from editorial policies rather than an attempt to revise Wieniewska's translation in order to bring it closer to the original. There are no additions or changes which would suggest that the editors consulted the Polish source text in the process (Ziemann, in preparation). 
coming a "Picador Classic" in 1988, a "Penguin $20^{\text {th }}$ Century Classic" in 1992, and a "Penguin Classic" in 2008. The translation is still available on the market. In 2015, it sold in 12,000 copies (Podstolski 2016).

\subsection{The Amateur: John Curran Davis}

More than four decades after the publication of Wieniewska's translation of the first Schulz volume, an interesting retranslation initiative followed. Around 2004, John Curran Davis, a Leedsbased teacher of media technologies, created the website schulzian.net (Schulz [undated]). Initially only listing links to various English-language articles on Schulz, from 2005 Davis started to put up online his retranslations of Schulz's stories, completing both volumes in 2010. At that time, Schulz's works were still protected by copyright, which expired only in 2013; hence Davis's was a copyright-infringing initiative. The fan retranslator promoted his work mainly among online communities of readers of popular genres, thus winning Schulz a new readership. Early in 2016, however, he crossed the border between free, unofficial circulation and official translation market, self-publishing Cinnamon Shops as a printed book (Schulz 2016), taking these stories down from his website and replacing them with links to Amazon, where his retranslation can now be purchased alongside Wieniewska's. The Sanatorium at the Sign of the Hourglass, as well as Davis's translations of Schulz's non-fiction writing (essays, letters, book reviews), are still available in open access at schulzian.net. ${ }^{5}$

\subsection{The Academic: Madeline Levine}

In 2011, Marek Podstolski, Bruno Schulz's closest living relative and manager of his estate, announced at an online forum used mainly by Schulz scholars that a new American retranslation of Schulz's works had been commissioned (Podstolski 2011). A few months later, he informed in a comment to Davis's online interview (Davis 2012) that it was being prepared under the auspices of the Polish Book Institute by Madeline Levine, an experienced translator and Professor of Polish Language and Literature at the University of North Carolina, Chapel Hill. Levine's work-inprogress received considerable publicity in both the source and target cultures. However, even though it was submitted to the Book Institute early in 2014 (Gauden 2014), Levine's retranslation of Schulz's collected stories is still only 'forthcoming'. After years of speculation, it was finally announced in the summer of 2017 that it will be published with Northwestern University Press in March 2018 (Northwestern University Press 2017); it is already available for pre-ordering from the publisher's website as well as from Amazon ${ }^{6}$.

Thus, the latest English Schulz translation has had an unusually prolonged and exposed nascence: the attention of Schulz readers was drawn to it already at the stage of commission, i.e. some three years before the text was even ready, and another three years have already passed since its completion, resulting in a paradoxical situation in which the retranslation 'is and is not' - we know it exists, and it is talked about, but only a handful of people have actually seen it. Despite

5 As this paper was under review, Davis's translations disappeared from schulzian.net. Since 2012, when I began visiting it regularly, the website had gone inactive several times, but, to my knowledge, never for longer than a few weeks (on retrieving archival online content, see Ziemann 2016: 107). The current situation is different in that the website itself is active under its usual address, but its new layout and content (advertisements!) suggests that is has been sold. Apart from the 2016 book edition, three stories in Davis's translation, which were published in 2012 and 2013 at http://weirdfictionreview.com/by/bruno-schulz/, are still available (last accessed 25 October 2017). Ironically, this surprising disappearance of the online retranslation corroborates my argument put forth later in this paper, namely that in the discourse surrounding Schulz translations, the fan retranslator himself is more visible than his text: unlike the retranslation, extratexts concerning his enterprise (e.g. Davis 2012) can still be found online.

6 This article was submitted long before I wrote a related chapter, in which I discuss Levine's translation as published and look at whether the preconceptions about Davis's and her versions are corroborated by the texts themselves (Ziemann 2018). However, due to publishing issues, the said chapter appeared in print first, while this article only follows now. Therefore, please see Ziemann 2018 for a more up-to date account. 
its 'inbetweenness', Levine's retranslation has already begun competing with Wieniewska's and Davis's version.

\section{Translator Profile in Discourse around Translation: Two Extremes}

\subsection{Translator Profile Absent from Discourse around Translation}

As we have seen above, Wieniewska's translation has been immensely successful in terms of publishing history. It also resonated strongly with readers, especially authors and artists. Not only Jewish-American writers (Isaac Bashevis Singer, Philip Roth, Cythia Ozick, Paul Auster, or, in the younger generation, Jonathan Safran Foer and Nicole Krauss), whose interest in Schulz could perhaps be explained partly in terms of the culture he belonged to and his tragic biography, but also a diverse host of other acclaimed authors (John Updike, Joyce Carol Oats, Angela Carter, J.M. Coetzee, Salman Rushdie, Ian McEwan, Michel Faber, Nadeem Aslam) and critics (Alberto Manguel, Susan Sontag, Francine Prose, V.S. Pritchett, John Bayley), as well as visual artists (Quay Brothers), theatre ensembles (Theatre de Complicite, to name just the best-known of Schulz's many adaptors) and musicians (from Björk to the American chamber music group Tin Hat) expressed admiration for Schulz or paid tribute to him (as translated by Wieniewska) in their own works.

Despite the success of her work, Wieniewska in many ways epitomizes translator invisibility, in both the intra- and extratextual sense of the word. At the level of paratext, only one of the twenty editions of her translation that I examined featured any information on the translator save for her name. The back flap of the first US edition of Sanatorium Under the Sign of the Hourglass (Schulz 1978) notes: "For her superb translation of The Street of Crocodiles, Celina Wieniewska was awarded the 1963 Roy Publishers Polish-into-English prize. She has also edited the collection Polish Writing Today". Most editions reprint her short translator's prefaces written to both volumes, introducing Bruno Schulz and his work to the anglophone reader (and not mentioning the actual business of translation). Although on the one hand this gesture can be seen as according a degree of visibility and recognition to Wieniewska, in fact the appearance of these texts in recent editions works to her disfavour, as they contain some information considered true in 1963 or 1978 but disproved since. For example, while Wieniewska writes that Schulz translated Kafka's The Trial into Polish, it was later discovered that the translation was actually done by his fiancée, Józefina Szelińska; Schulz revised it and he gave his name to it, presumably because it was hoped that his literary reputation would boost Kafka's success in Poland. It is baffling indeed that publishers today reproduce such factual mistakes.

At the level of the extratext, after more than three decades of uncritical acceptance in the target culture, around the turn of the $21^{\text {th }}$ century - much like the Muirs' Kafka, Scott Moncrieff's Proust, Lowe-Porter's Mann and many other older English translations of European classics - Wieniewska's translation began to be criticized for cuts, omissions, avoidance of the author's repetitions, smoothening of his thick meandering prose, in short - for 'Englishing' his writing to make it more readable. Some of these critical remarks are very harsh: Wieniewska has been accused of an "incredibly arbitrary destruction of the Polish text" (Banks 2009: 62) which "borders on literary criminality" (Banks 2009: 58). "Whenever the translator can't cope with the linguistic thicket of Schulz's language (usually by pruning away with the translator's secateurs)," Michał Paweł Markowski, professor of Polish literature at the University of Illinois at Chicago, writes, "she blithely omits the troublesome sentences, thus entirely erasing the writer's signature" (Markowski 2009). ${ }^{7}$

7 Translation accuracy is, of course, notoriously difficult to measure, and putting these criticisms to the test of comparative textual analysis is beyond the confines of the present paper. My research (Ziemann, in preparation) so far suggests that although Markowski and others are clearly right about the fact that Wieniewska cut Schulz's prose, her 'trimming' (to preserve the gardening metaphor) did not make such a great difference as they claim. As Antoine Berman observed, "In certain kinds of masterly prose the original text system is so consolidated (and, additionally, it exhibits some redundancy of markers) that even their omission in the translation does not annihilate the system as a whole" (Berman 1999 [1985] quoted in Brzozowski 2004: 216; my translation). Accumulating the same stylistic 
None of the critics presenting Wieniewska as ignorant, careless or downright incompetent reflect on whether her translation choices were deliberate or what might have been her reasons, let alone who she was. They do not take into account the time and context in which the translation was made, or the fact that in 1963 the now-acclaimed Schulz was essentially a debutant abroad, and even in Poland his position was nowhere near the canonical status he enjoys today. Seen in such a decontextualized perspective, Wieniewska indeed comes across as a poor translator, mistakenly entrusted with the task she was not up to, since she failed to appreciate Schulz's undisputable greatness.

However, research into the translator's biography reveals a different image. Wieniewska, who fled Poland at the outbreak of WW2 and settled in London, marrying the literary agent Peter Janson-Smith, worked not only as a translator but also as a representative of a number of European publishing houses. She regularly visited the Frankfurt Book Fair. She maintained contacts with both the Polish diaspora and London literary circles. Through her husband, she knew Ian Fleming and Anthony Burgess, among other authors. She was friends with the avant-garde artists Stefan and Franciszka Themerson of the Gaberbocchus Press, and knew the editors of the Polish-language weekly Wiadomości, the émigré continuation of pre-war Warsaw Wiadomości Literackie, where Bruno Schulz made his debut and published stories and literary criticism throughout the 1930s. She was also the editor of Penguin's anthology Polish Writing Today (Wieniewska 1967). The Times described her in an obituary as a "charming, courageous and forceful personality" and a "symbol of the indomitable spirit of the Polish community in London" (The Times 1985).

This would be merely circumstantial evidence of Wieniewska's stature had it not been for her correspondence. Wieniewska's letters testify to her profound knowledge of the publishing market and her remarkable awareness of the mechanisms governing the production and circulation of translated literature, which certainly informed her work as a translator. To take one example, rejecting a book by a lesser Polish author who turned to her as a prospective translator and agent, Wieniewska concluded her long letter as follows:

\begin{abstract}
please bear in mind that anglophone markets are not receptive towards translated literature, especially not from lesser-known languages. The situation is somewhat better than it used to be - also thanks to the fact that the Germans have translated many Polish books - but it's still not quite good. ... As regards Polish authors, I get the impression that at the moment it is relatively easier to place here good poetry and drama than fiction. (Wieniewska 1969; this and all subsequent translations from Wieniewska's letters are mine)
\end{abstract}

This short passage can be easily translated into the terms of translation theory: in 1969, Wieniewska speaks of the self-complacency of anglophone literature later criticised by Venuti, and notices that existing translations of books from a smaller language (peripheral like Polish) into a bigger one (central like French or German) facilitate the publication of translations into (hyper-central) English, as indicated by the sociologist Johan Heilbron (Heilbron 1999, Heilbron/van Es 2015). Also her intuition concerning the preferred translated genres, echoing the dynamically changing central and peripheral literary subsystems which we know from polysystem theory, was correct. ${ }^{8}$

Although I did not come across letters directly concerning Wieniewska's work on Schulz, her other correspondence gives insight into her motivations and attitudes. For example, in an ex-

devices (multi-tiered metaphors and extended similes relying heavily on personification, repetitions and strings of synonyms or near-synonyms) page after page, Schulz can be regarded as an author of precisely this kind of translatableuntranslatable "masterly prose".

8 Unlike Polish fiction, Polish poetry indeed came to be esteemed by British critics (e.g. Al Alvarez), poets (e.g. Ted Hughes) and readers in the 1960s, following the publication of Postwar Polish Poetry, a selection edited and translated by Czesław Miłosz (1965), and Zbigniew Herbert’s Selected Poems featured in the influential series Penguin Modern European Poets (1968). Poems by Herbert, Tadeusz Różewicz and Wisława Szymborska, future recipient of the 1996 Nobel Prize in Literature, were included also in Wieniewska's 1967 anthology. Polish drama was represented in English for example by the plays of Sławomir Mrożek (1967), whose name was made by Tom Stoppard's 1966 adaptation of Tango for the Royal Shakespeare Company. 
change with the eminent Polish writer Maria Kuncewicz, whose edited volume The Modern Polish Mind (1962), published only a year before The Cinnamon Shops, features five prose pieces in Wieniewska's translation, the translator explicitly and unapologetically states that she performed an "extensive cosmetic surgery" on a short story by Jarosław Iwaszkiewicz and that "it is better now" (Wieniewska 1961). However, this boldness on the part of the translator should not be mistaken for disrespect or irreverence for the author: elsewhere, Wieniewska calls Iwaszkiewicz, who was the first author she translated into English back in 1942, "the best, even on world scale, when it comes to the short story" (Wieniewska 1967). To the author whose text she allegedly destroyed, she refers as "my beloved Schulz". While explaining her choice of pieces for the Penguin anthology, she asserts that whatever decisions she took, "they resulted from long deliberations and even longer discussions with the series editor" (Wieniewska 1967).

Thus, it can be safely inferred that Wieniewska's treatment of Schulz was deliberate and informed by her knowledge of the publishing market, rather than resulting from her failure to appreciate his style, her carelessness or linguistic incompetence. Confident in her power of judgement and her translation skills, she did what she felt to be necessary to secure Schulz a wide readership - and, as shown in the overview of her translation's publishing history in the previous section, in this respect she succeeded. Whatever our ex post evaluation of her translation choices, they cannot be called random; Wieniewska knew very well what she was doing.

Apart from excessive domestication of Schulz's style, the other, perhaps more serious criticism voiced against Wieniewska - by none less than the Nobel Prize winner J.M. Coetzee - was that she 'universalized specifically Jewish allusions' (Coetzee 2003). ${ }^{9}$ Again, without the biographical context this could suggest ignorance or - given the image of Polish anti-Semitism common in the West - perhaps even resentment on the part of the Polish translator. However, when one learns that Celina Wieniewska (Janson-Smith), was actually born to Jewish parents as Celina Miliband ${ }^{10}$, that both her parents, like Schulz, perished in the Holocaust, that between the two Schulz volumes, she also translated two poignant novels portraying Jewish life in Poland - Julian Stryjkowski's The Inn (1966) and Henryk Grynberg's Child of the Shadows (1969; original Polish title: Żydowska wojna, "The Jewish War") - and, finally, that apart from The Times, her obituary was published in the bulletin of the Association of Jewish Refugees in London, it transpires that Wieniewska could relate to Schulz's Jewishness better than any of her future critics and defenders of 'Jewish allusions'.

As I have demonstrated elsewhere (Ziemann 2017b), in fact Wieniewska accurately rendered culturally specific vocabulary referring to the shtetl reality (e.g. names of garments traditionally worn by Orthodox Jews in Galicia), which Schulz actually uses quite sparsely. What might be meant by the alleged 'universalization of allusions' (neither Coetzee nor Robertson offer examples) is that when faced with a choice between a lexical solution that would allow but not impose Judaist interpretation and one that would inevitably point to such a reading, she opted for the former. To give two examples, she translated Schulz's księga blasku, where contemporary critics see an allusion to the Zohar, as book of light rather than book of splendour, and she opted for the more general treatise as the translation of Schulz's traktat (which in Polish is also general: it can refer to a philosophical or political treatise) as opposed to the Talmudic tractate. Wieniewska probably assumed, not without a reason, that her target reader would not be familiar with the Kabbalah or the Talmud just as, arguably, generations of readers of the Polish original missed these references; it was only decades later that this interpretive paradigm gained popularity in Schulz Studies (see

9 This is an interesting case of second-hand criticism; having no access to the Polish original, Coetzee repeats the critique voiced by Theodosia Robertson, the American translator of Ficowski's biography of Schulz (Ficowski 2003). Although he references Robertson, whose discussion of Wieniewska's translation was balanced and took context into account, and he also praises Wieniewska's "rare richness, grace, and unity of style", it is the negative part of this review that later gets repeated on readers' blogs, and it is Coetzee's, not Robertson's, name that gives authority to the criticism (for a discussion of the refractions of Coetzee's remarks on the Internet, see Ziemann 2014).

10 This is not a coincidence; Wieniewska's branch of the family was related to the great-grandfather of David and Ed Miliband of the Labour Party (Will/Luck 2009). 
e.g. Goldfarb 1994). Moreover, in employing this sort of 'universalization', in a sense Wieniewska followed Schulz himself, who, according to Karen Underhill (2016), developed an aesthetic

shaped by and drawing upon the world of east European Jewish literary, hermeneutic and narrative
tradition, while at the same time choosing to actively encrypt, downplay or universalize that Jewish
content, producing a layered or slashed narrative space that was both Jewish and transnational.

As can be seen, archive research on Celina Wieniewska's life and work puts the recent criticism of her translation in an entirely new light. It reveals that the success of Wieniewska's translation was not accidental and should not be taken for granted; Schulz has not earned such popularity with Anglophone readers 'in spite of' but 'thanks to' his translator, who was a true ambassador of the kind described by Francis R. Jones in the context of another 'small' literature (Yugoslavian) trying to find its place on the anglophone market: apart from translating, she had to "package and promote [her writer] in such a way that publishers, journal editors, reviewers, and the public see [him] as worth publishing and reading" (2011: 65). Whatever the faults of her version and whatever its future, Wieniewska deserves credit as the co-author of Schulz's success rather than being remembered solely as the wielder of 'translator's secateurs'.

\subsection{Translator Profile Dominating Discourse around Translation}

The position of Wieniewska's successors with respect to discourses around their translations is radically different: their profiles can be said to be more visible than their texts, albeit in different respects, for different reasons and with different effects. John Curran Davis, the originator of schulzian.net, where his translations were published, is highly visible on the paratextual level. Not only does his name appear on the homepage, but clicking on it triggers the visitor's default email client to open a draft letter to the translator - a sign of approachability but also an assertion of control over the website. The homepage also features a link to a long interview Davis gave to the online portal Weird Fiction Review (Davis 2012) - an example of epi/peri-text in one: paratextual material at once removed from and included in the translated text.

Run by Ann and Jeff VanderMeer, WFR defines itself as "an ongoing exploration into all facets of the weird, in all of its many forms - a kind of non-denominational approach that appreciates Lovecraft but also Kafka, Angela Carter and Clark Ashton Smith, Shirley Jackson and Fritz Leiber" (Weird Fiction Review). Accordingly, Davis's interview opens with reminiscences, recounted in a casual, personal tone, of his childhood fascination with horror films and literature: he immediately presents himself as a fan of popular genres, member of the WFR community. Also other personal information that he offers distances him from the high-brow: he mentions that his parents "were not great readers", his father thinking "none too highly of Shakespeare, or of those who read him, who did so, in his eyes, for some spurious reason of status", and that his "day job" is "in the Creative Studies department of a school . . advising students on how to make short films and animations" (Davis 2012).

Davis, an amateur in both senses of the word: a non-professional and an aficionado (for a discussion of his initiative in the context of fan translation, see Ziemann 2016), goes on to present a romantic story of his first encounter with Schulz, whose work he first read in English while on a student exchange in Poland, and fell in love at first sight: "I claim, I maintain, I swear that, before I had reached the bottom of the first page, I knew that, one day, I would read Bruno Schulz in the original. And that is how the translation began". Interestingly, he openly admits (and even seems to take some pride in the fact) that he had not known Polish prior to his visit ("In preparation for this adventure, I optimistically bought Teach Yourself Polish") and that working on Schulz's fiction was his first translation experience ("I became a translator precisely because of my encounter with Bruno Schulz. Until then, I don't think the thought had ever entered my mind"). Not only does he not worry about his translation competence, but he also states with a remarkable degree of self-confidence that "Bruno Schulz is not quite so difficult to translate as it is sometimes claimed or assumed" (Davis 2012). 
Ignoring the fact that it was Wieniewska's English version that made him fall in love with Schulz, Davis has nothing but criticism for it:

I must take issue with that translation on several grounds. There are some quite basic blunders; many
words and phrases are simply mistranslated. But worse are the ellipses, the passages simply omitted.
There is a sense of paraphrase, of too much explanation, of shying away from taking a challenge. (Da-
vis 2012)

Like her critics quoted in the previous section, he does not say a word about the translator herself or about the context of her work.

The retranslator assumes the position of an expert on Schulz, answering questions about the characteristics of the Polish author's fiction, his humour, his affinity with Kafka, and even the present-day condition of Schulz Studies: "He appeals strongly to academics, and his life and work have inspired a great deal of commentary and analysis, much of which is of significant interest". He also expresses some reservations towards translation theory:

\begin{abstract}
Incidentally, I have been asked many times about my approach in the rarified [sic] terms of critical theory, which can be mildly irritating as there seem to be ever present, unstated assumptions involved when someone asks what "translation dominants" one employs, or when someone matter-of-factly states that "translation is always an expression of power". One should read up on translation theory; and subscribe to not a word of it. (Davis 2012)
\end{abstract}

But if he had been approached by academics familiar with rarefied theoretical terms, it must have been in personal communication, for there is hardly any evidence of interest in his translation in official publications. ${ }^{11}$ The interview does not mention one important fact about Davis's initiative, which, alongside the retranslator's lack of institutional/publishing patronage and lack of experience (lack of cultural capital, translation sociologists would say), is the reason for its absence from critical discourse: by making his translations available online, Davis infringed the copyright, and thus his work did not have the legal status of a translation. I have discussed this aspect of Davis's project elsewhere (Ziemann 2016); here, suffice it to say that his retranslation is seldom quoted or mentioned in English-language literature on Schulz, and, to my knowledge, it has never been publically discussed at length or compared with Wieniewska's by literary critics, even those dissatisfied with the earlier version. This has not changed even with the expiry of the copyright and the recent self-publication of The Cinnamon Shops in traditional book format.

Thus, it can be said that although Davis actively promotes his work online, and his translation is discussed by 'lay' readers on forums and blogs ${ }^{12}$, the official literary market and academic world chose to ignore the retranslation, not on the account of its quality or textual characteristics, but because of the context of its production: its originally dubious legal status and the retranslator's profile, which does not fit in with the expectations one would have of a retranslator of a canonical author writing highly sophisticated prose. In that sense, in Davis's case the translator's profile has played a more important role in the critical reception of his work than his actual translation choices - a situation directly opposite to Wieniewska's, but equally if not more unfair.

Unlike Davis, Madeline Levine enjoyed institutional support right from the start, but, again unlike Davis, she did not present herself as Schulz retranslator of her own accord; she was 'made visible' by others. One of the comments under Davis's interview reads:

11 This does not mean that academics do not read his translation or use it in class (in fact, I know at least two who do, one in Poland and one in the US); what I am saying is that they do not use it in their published work.

12 One good case in point is a piece on Schulz on The Guardian's book blog (Power 2010): in the main body of the text, the author discusses Schulz without any reference to translation whatsoever; in the comments section, he adds a note on Wieniewska's translation, quoting Coetzee. This is followed by another reader's comment: "Celina Wieniewska's translation ... has been discredited for being woefully inaccurate. We continue to be forced to endure this translation because the Bruno Schulz estate refuses permission for anything else to be published! A much more sophisticated translation can be found at http://www.schulzian.net". Other readers join in and a heated debate (ca. 70 comments!) on the quality of Davis's translation ensues, with the participation of the retranslator himself. 
As the executor to Bruno Schulz's Estate and the copy right [sic] owner, I have the pleasure to inform you all, that Polish Book Institute has commissioned, with my blessing, Prof. Dr. Madeline G. Levine from University of North Carolina to translate works of Bruno Schulz into English. (Marek Podstolski's online comment in Davis 2012)

As can be seen, Levine's academic affiliation and institutional patronage is immediately foregrounded. It is also important to note that Podstolski does not refer to the quality of Davis's retranslation in any way; he merely implies its inferiority by advertising Levine's work.

Later that year, Madeline Levine became visible in the discourse around her translation in the very literal sense of the world, speaking at three events: the Bruno Schulz Festival in the author's native Drohobych (present-day Ukraine), the Bruno Schulz Festival in Wrocław (Poland), and the After Schulz Festival in Chicago. The first event included a short announcement of her work on Schulz; the second featured a panel discussion in which Levine participated alongside Schulz's Hebrew, Chinese, and Ukrainian translators, whose work had been published; in Chicago, Levine read excerpts from her translation of one story. It is quite telling that the organizers invited the American scholar, whose translation of Schulz, technically speaking, did not exist, rather than Davis, of whose work they might have not been aware, or, if they were, it still 'did not exist' for them in the symbolic sense.

Also in 2012, a long interview with Madeline Levine appeared in Polish in Tygodnik Powszechny, a socio-cultural weekly with a wide readership (Levine 2012). A short accompanying bio note introduced her as an award-winning translator (the listed examples of authors she translated included mainly contemporary Polish-Jewish writers) and scholar specializing in Slavic and comparative literature, as well as translation theory. It is interesting to read Levine's interview in juxtaposition with Davis's quoted above; save for their admiration for Schulz, the two retranslators differ in almost all ways imaginable. What they have in common is that their views are public.

Levine's tone is less personal; nor does she offer personal information. In the very first sentence, in response to a question about the impossibility of translating Schulz, she presents herself as an experienced professional: "If I hadn't believed in the possibility of a good translation, I wouldn't have been active as a translator for the past forty years" (Levine 2012, this and subsequent translations are mine). At the same time, she comes across as modest and humble, with respect to both the task of translating Schulz and to Wieniewska's work.

"Bruno Schulz's stories are located in the upper realms of translatorial impossibility", Levine says, in stark contrast to Davis. She speaks respectfully of Wieniewska, acknowledging the canonical status of the older translation, which she often used herself when teaching Polish $20^{\text {th }}$ century literature. Levine mentions also the psychological pressure of knowing that her retranslation would be compared not only with the original, but also with Wieniewska's version - something Davis either did not feel or admit - and says that she consulted the older translation, because, knowing it so well, she would not have been able to avoid its influence anyway ("the rhythm of her English, as well as certain images, established themselves, consciously or not, in my memory"). Although both Davis's and Levine's retranslations are active (Pym 1998: 82-83), i.e. done with the awareness of and with a view to improving on Wieniewska, and both retranslators can be said to exhibit a certain anxiety of influence (Koskinen/Paloposki 2015), they react to the early translation in radically different ways.

Prompted by the interviewer to list the weak points of Wieniewska's translation, Levine offers a very even-handed critique. She points out that the translator did not attempt to reconstruct all "mannerisms of Schulz's style", simplifying them for the reader, making Schulz adhere to "the rules of good English composition", and seeking naturalness of expression. Nevertheless, the retranslator shows understanding for Wieniewska's choice of strategy and discusses the shortcomings of the early translation in much milder terms than some other critics:

The differences will not be radical; my version is not going to bring fundamental revelations concerning omitted scenes, changed order of chapters or other scandalous defects, which usually come to light when retranslations of works long present in the English language are published. My version 
will certainly have a different timbre and will be informed by my theories of how one should go about translating. (Levine 2012)

Given her academic affiliation, it is not surprising that Levine differs from Davis also in her opinions on translation theory. In the interview, she references Robert Wechsler's book Performing Without a Stage: The Art of Literary Translation, while at the Bruno Schulz Festival translators' panel, she explicitly endorsed Venuti, pledging allegiance to "his foreignizing school".

At one of the literary festivals, Levine responded to a question about the respective translators' solutions to difficulties posed by Schulz's style with a kind of disclaimer, saying that her translation was still a work-in-progress, so it would be easier for her to speak of what she would like to avoid rather than of solutions she had found. Apart from the three festivals and the above-quoted interview, Levine does not seem to have actively promoted her work; however, the publicity machine was set in motion and her project has excited Polish and international Schulz scholars since its announcement by Podstolski. On the other hand, this pre-publication coverage elicited comments such as: "Levine's translation is being prematurely heralded in the Polish press, but in fact nothing has been published, which if not the cart before the horse I don't know what is" (online comment in Davis 2012). Although one may frown at the rhetoric of this online post by a fan of Davis's translation, one must admit that he has a point.

The delay in publishing Levine's retranslation was apparently caused by copyright issues which neither the commissioner nor the copyright holder, Marek Podstolski, had foreseen: it turned out that the publishing company which holds rights to Wieniewska's translation also had the right of pre-emption for a retranslation but, given the success of the old translation, they turned down the offer to publish Levine's version. This, in turn, discouraged other publishing houses from taking the commercial risk (Podstolski 2016). It is also rumoured that the foreignizing, source-oriented retranslation did not meet with full approval of internal reviewers, who found it too uncompromising and requested revisions.

Such a situation is undoubtedly uncomfortable for the retranslator herself, increasing the psychological pressure she mentioned with respect to being compared to Wieniewska. Thus, on the one hand, the publicity surrounding Levine's own retranslation turned against her, blowing the bubble of expectations. On the other hand, just as Davis's translation was rejected, Levine's was - at least for the time being - enthusiastically accepted in academic circles based on the translator's profile and other contextual, not textual, factors.

\section{Conclusions}

The above discussion featured examples of different degrees and effects of translator (in)visibility in discourses around translation: invisibility working against a translator, increased visibility working against a (re)translator, and increased visibility working in a (re)translator's favour - in a certain context, among certain audiences. It shows the complexity of mechanisms and dynamics of the circulation of translated literature, and warns us against hastily and automatically according positive value to any concepts or phenomena, even if they seem "easy to agree with" like translator visibility (Koskinen 2000: 98).

On one level, the conclusion is obvious to the point of triviality: both text and its context, both the translator and his or her actual work, should be taken into account in evaluating a translation, since ignoring one or the other may lead to critical assessments that are underinformed at best, and sometimes simply unfair. More interesting is of course the question of how to make this happen. Both professional literary critics reviewing translations for the press and readers blogging about translated books face obvious practical constraints of time, space, and language: naturally, it cannot be expected of them to do extensive research on the biographies of translators and other contextual issues before discussing the actual translations. What would make a difference, however, and could be achieved at no extra cost or effort, would be a change of rhetoric: if critics cannot - often understandably, let me reiterate - take into account the translator as a person acting in 
a particular context, it would help, I believe, to make the criticism impersonal and speak of the translation's and not the translator's faults.

Much has been said in both academic and non-academic discussions about the ethical dimension of the translator's work; perhaps it is time to problematize also the ethics of translation criticism. This is not to argue that only positive translation evaluation should be welcome in critical discourse, as this would mean censorship; what I am suggesting is simply that the critics' constraints should be made explicit. After all, if the translator is burdened with responsibility, because his or her translation usually replaces the original for the target reader, who, consciously or not, trusts in the translator's ethics, the translation critic bears a similar kind of responsibility and is also endowed with the reader's trust, since a review or opinion may replace the translation - at least temporarily, at least for some readers.

On the other hand - not to be critical only of critics - TS scholars, who can and do engage in indepth research into the contexts (also human) of translation production, could get more involved in extra-academic discussions about translation, not only sharing their findings in the form of lengthy pieces in specialized journals such as this one, but also making use of other communication platforms and drawing the general reader's attention to the problem of translator (in)visibility and other issues that they find have been overlooked by critics, publishers or other stakeholders (see Ziemann 2017a). Now that discourse about translated literature takes place largely online, and is often interactive, it is relatively easy to enhance the researcher's visibility and activism in this way. Even though participating in 'lay' discussions about translation is usually not rewarded by our university departments, without our extra-academic engagement the project of a 'translation culture' as envisaged by Venuti (2013b), a culture in which the phenomenon translation is reflected on in all its complexity rather than being treated instrumentally and assessed based on first impressions, will remain utopian.

It is sobering to recall that it was in the early 1970s that James Holmes argued: "The level of [translation] criticism is today still frequently very low, and in many countries still quite uninfluenced by developments within the field of translation studies" and appealed for "closer contact between translation scholars and translation critics" (Holmes 1972: 78). If loss of relevance or insufficiency of his model for present-day developments in the discipline, e.g. Translator Studies, should be welcome as a clear sign of growth and progress, the arguable relevance of the abovequoted diagnosis serves as a reminder of the applied, i.e. 'difference-making' dimension of scholarly work. 


\section{References}

Banks, Brian 2009: Muse and Messiah: The Life, Imagination and Legacy of Bruno Schulz (1892-1942). [place not indicated]: InkerMen Press.

Berman, Antoine 1999 [1985]: La Traduction et la lettre ou L'auberge du lointain. Paris: Seuil.

Brzozowski, Jerzy 2004: Fabuła czy poezja? Bakakaj po portugalsku [Plot or poetry? Bacacay in Portuguese]. In Skibińska, Elżbieta (ed.): Gombrowicz i thumacze [Gombrowicz and his translators]. Lask: Oficyna Wydawnica Leksem.

Chesterman, Andrew 2009: The Name and Nature of Translator Studies. In Hermes 42, 13-22.

Coetzee, John Maxwell 2003: Sweet Persuasions in the Dark. In The New York Review of Books [online]. http://www. nybooks.com/articles/2003/02/27/sweet-persuasions-of-the-dark/ (accessed 12 June 2017).

Coetzee, John Maxwell 1998: Kafka: Translators on Trial. In The New York Review of Books [online]. http://www. nybooks.com/articles/1998/05/14/kafka-translators-on-trial/ (accessed 12 June 2017).

Deane-Cox, Sharon 2014: Retranslation: Translation, Literature and Reinterpretation, London/New Delhi: Bloomsbury Publishing.

Dam, Helle V./Koskinen, Kaisa (eds.) 2016: The Journal of Specialised Translation 25.

Davis, John Curran 2012: Interview: Translator John Curran Davis on Polish Writer Bruno Schulz. In Weird Fiction Review, 23 Jan. [online]. http://weirdfictionreview.com/2012/01/interview-translator-john-curran-davison-polish-writer-bruno-schulz/ (accessed 20 Oct. 2017).

Fawcett, Peter 2000: Translation in the Broadsheets. In The Translator 6 (2), 295-307.

Ficowski, Jerzy 2003: Regions of the Great Heresy. Bruno Schulz: A Biographical Portrait. Trans. Theodosia Robertson. New York/London: W.W. Norton.

Gauden, Grzegorz 2014: Książka przetrwa [The book will survive]. Interview. In Kurier Galicyjski 18 Feb. [online]. http://www.kuriergalicyjski.com/index.php/rozmowy/3045-ksi-ka-przetrwa (accessed 20 June 2017).

Genette, Gérard 1997: Paratexts: Thresholds of Interpretation. Translated by Jane E. Lewin. Cambridge: Cambridge University Press.

Goldfarb, David 1994: A Living Schulz. 'Noc wielkiego sezonu' ('The Night of the Great Season'). In Prooftexts 14(1), $25-47$.

Heilbron, Johan 1999: Towards a Sociology of Translation. Book Translations as a Cultural World-System. In European Journal of Social Theory 2(4), 429-444.

Heilbron, Johan/van Es, Nicky 2015: Fiction from the Periphery: How Dutch Writers Enter the Field of EnglishLanguage Literature. In Cultural Sociology 9(3), 296-319.

Hermans, Theo 1999: Translations in Systems: Descriptive and System-Oriented Approaches Explained. Manchester: St. Jerome Publishing.

Holmes, James 1972: The Name and Nature of Translation Studies. Paper presented at the Third International Congress of Applied Linguistics. Expanded pre-publication version [online]. https://archive.org/details/Holmes1972TheNameAndNatureOfTranslationStudies (accessed 20 June 2017).

Horton, David 2013: Thomas Mann in English: A Study in Literary Translation, London/New Delhi: Bloomsbury Publishing.

Jarzębski, Jerzy 1996 (ed.): Gombrowicz. Walka o sławę. Korespondencja Witolda Gombrowicza z Józefem Wittlinem, Jarostawem Iwaszkiewiczem, Arturem Sandauerem [Gombrowicz: The fight for fame. Witold Gombrowicz's correspondence with Józef Wittlin, Jarosław Iwaszkiewicz, Artur Sandauer]. Kraków: Wydawnictwo Literackie.

Jones, Francis R. 2000: The Poet and the Ambassador: Communicating Mak Dizdar's Stone Sleeper. In Translation and Literature 9(1), 65-87.

Koskinen, Kaisa 2000: Beyond Ambivalence. Postmodernity and the Ethics of Translation. Tampere: University of Tampere [online]. http://tampub.uta.fi/handle/10024/67049 (accessed 20 oct. 2017).

Koskinen, Kaisa/Paloposki, Outi 2015: Anxieties of Influence. The Voice of the First Translator in Retranslation. In Target 27(1), 25-39.

Kuncewicz, Maria (ed.) 1962: The Modern Polish Mind, Boston/Toronto: Little Brown \& Co.

Levine, Madeline 2012: Głos Schulza [Schulz's voice]. Interview. In Tygodnik Powszechny 50 [online]. https://www. tygodnikpowszechny.pl/glos-schulza-17931 (accessed 20 June 2017).

Maier, Carol 2009: Reviewing and Criticism. In Baker, Mona/Saldanha, Gabriela (eds.): Routledge Encyclopedia of Translation Studies, ${ }^{\text {nd }}$ Ed. Lonon/New York: Routledge, 236-241. 
Markowski, Michał Paweł 2009: The Republic of Dreams. Translated by Stanley Bill [online]. http://brunoschulz.eu/ en/archiwa/49 (accessed 20 June 2017).

Munday, Jeremy 2014: Using Primary Sources to Produce a Microhistory of Translationand Translators: Theoretical and Methodological Concerns. In The Translator 20 (1), 64-80.

Schulz, Bruno 2017: Collected Stories. Translated by Madeline G. Levine. Evanston: Northwestern University Press Publisher's information [online]. http://www.nupress.northwestern.edu/content/collected-stories (accessed 20 Oct. 2017).

The Times 1985: Obituary of Celina Janson-Smith. 19 October 1985.

Olohan, Maeve/Baker, Mona 2009: Coherence and Clarity of Objectives in Doctoral Projects: A Research Design Workshop. In The Interpreter and Translator Trainer 3 (1), 143-64.

Paloposki Outi 2012: Translation Criticism. In Gambier, Yves/Van Doorslaer, Luc (Eds.). Handbook of Translation Studies. Amsterdam/Philadelphia: John Benjamis, 184-190.

Paloposki, Outi/Koskinen, Kaisa 2004: A Thousand and One Translations: Revisiting Retranslation. In Hansen, Gyde/ Malmkjaer, Kirsten/Gile, Daniel (eds.): Claims, Changes and Challenges in Translation Studies: Selected contributions from the EST Congress, Copenhagen 2001, 27-38.

Podstolski, Marek 2016: Personal email correspondence.

Podstolski, Marek 2011. Internet forum entry. 16 Sept. [online]

http://www.brunoschulz.org/gosci2.htm (accessed 20 June 2017).

Power, Chris 2010: A Brief Survey of the Short Story Part 30: Bruno Schulz. In The Guardian 3 Dec. [online]

https://www.theguardian.com/books/booksblog/2010/dec/03/brief-survey-short-story-bruno-schulz. (accessed 20 June 2017).

Pym, Anthony 1998: Method in Translation History. London/New York: Routledge.

Schulz, Bruno [undated]: Bruno Schulz's Stories and Other Writings, Trans. John Curran Davis. [online]. schulzian.net (accessed 20 June 2017).

Schulz, Bruno 2016: The Cinnamon Shops and Other Stories, Trans. John Curran Davis. [no place or publisher named].

Schulz, Bruno 2012: The Fictions of Bruno Schulz: The Street of Crocodiles, Sanatorium Under the Sign of the Hourglass. Trans. Celina Wieniewska. London: Picador.

Schulz, Bruno 2011: Sanatorium Under the Sign of the Hourglass. Trans. Celina Wieniewska. In VanderMeer, Jeff/ VanderMeer, Ann (eds.): The Weird: A Compendium of Strange and Dark Stories, London: Corvus, 248-259.

Schulz, Bruno 2008: The Street of Crocodiles and Other Stories. Trans. Celina Wieniewska. New York: Penguin.

Schulz, Bruno 1998: The Street of Crocodiles. Trans. Celina Wieniewska. In Stavans, Ilan (ed.): Oxford Book of Jewish Stories, Oxford/New York, 117-124.

Schulz, Bruno 1988: The Fictions of Bruno Schulz: The Street of Crocodiles, Sanatorium Under the Sign of the Hourglass. Trans. Celina Wieniewska. London: Picador.

Schulz, Bruno 1978: Sanatorium under the Sign of the Hourglass. Trans. Celina Wieniewska Walker\&Co.: New York.

Schulz, Bruno 1977: The Street of Crocodiles. Trans. Celina Wieniewska. New York: Penguin.

Schulz, Bruno 1963a: Cinnamon Shops and Other Stories. Trans. Celina Wieniewska. London: MacGibbon\&Key.

Schulz, Bruno 1963b: The Street of Crocodiles. Trans. Celina Wieniewska. New York: Walker\&Co.

Sela-Sheffy, Rakefet/Schlesinger, Miriam (eds.) 2011: Identity and Status in the Translational Professions. Amsterdam/ Philadelphia: John Benjamins.

Sela-Sheffy, Rakefet 2014: Translators' Identity Work: Introducing Micro-sociological Theory of Identity to the Discussion of Translators' Habitus. In Vorderobermeier, Gisella M. (ed.). Remapping Habitus in Translation Studies, Amsterdam/New York: Rodopi, 43-55.

Sela-Sheffy, Rakefet 2008: The Translators' Personae: Marketing Translatorial Images as Pursuit of Capital. In Meta 53(3), 609-622.

Susam-Sarajeva, Şebnem 2009: The Case Study Method in Translation Studies. In The Interpreter and Translator Trainer 3 (1), 37-56.

Stojanowić, Branislava [undated]: brunoschulz.org [database of editions and reference literature on Schulz] http:// www.brunoschulz.org/wydania.htm (accessed 5 June 2017).

Tahir Gürçağlar, Şehnaz 2011: Paratexts. In Gambier, Yeves/Van Doorslaer Luc (eds.). Handbook of Translation Studies, Vol. 2, Amsterdam/Philadelphia: John Benjamins, 113-117.

Underhill, Karen 2016: Paper delivered at the Jagiellonian University, 20 June. 
Vanderschelden, Isabelle 2000a: Quality Assessment and Literary Translation in France. In: The Translator 6 (2), 271-293.

Vanderschelden, Isabelle 2000b: Why Retranslate the French Classics? The Impact of Retranslation on Quality. In Salama-Carr, Myriam (ed.): On Translating French Literature and Film II. Amsterdam Rodopi.

Venuti, Lawrence 2013a [2004]: Retranslations: The Creation of Value. In Translation Changes Everything: Theory and Practice. London/New York: Routledge, 97-108.

Venuti, Lawrence 2013b [2011]: Towards a Translation Culture. In Translation Changes Everything: Theory and Practice. London/New York: Routledge, 231-248.

Venuti, Lawrence 1998: The Scandals of Translation: Towards and Ethics of Difference. London/New York: Routledge.

Venuti, Lawrence 1995: The Translator's Invisibility: A History of Translation. London/New York: Routledge.

Weird Fiction Review [undated]. 'About' section. [online] http://weirdfictionreview.com/about/ (accessed 15 June 2017).

Wieniewska, Celina 1969: Letter to Piotr Guzy. 3 July. Manuscript held at the Emigration Archive, Toruń University Library, Poland: Piotr Guzy Collection.

Wieniewska, Celina 1967: Letter to Michał Chowaniec. 5 Sept. Manuscript held at the Emigration Archive, Toruń University Library, Poland: Wiadomości Collection.

Wieniewska, Celina 1961: Letter to Maria Kuncewicz. 17 Sept. Manuscript held in Ossolineum Library, Wrocław, Poland: Maria Kuncewicz Collection.

Will, Stewart/Luck, Adam 2009: From Foiling the Nazis to Marrying 007's Friend: The Rip-roaring Life of David Miliband's Lost Cousin. In Daily Mail 8 Nov. [online]. http:/www.dailymail.co.uk/news/article-1225984/ Milibands-lost-cousin-The-beauty-foiled-Nazis-married-007s-friend.html (accessed 15 June 2017).

Woods, Michelle 2014: Kafka Translated: How Translators have Shaped our Reading of Kafka. New York/London/ New Delhi/Sydney: Bloomsbury Publishing.

Ziemann, Zofia (in preparation): Bruno Schulz w angielszczyźnie 1958-2016. Historia i recepcja przekładów, z elementami analizy porównawczej [Bruno Schulz in English 1958-2018. Translation history and reception, with comparative textual analysis]. Unpublished PhD dissertation, Jagiellonian University, Kraków.

Ziemann, Zofia 2018: Extratextual Factors Shaping Preconceptions About Retranslation: Bruno Schulz in English. In Berk Albachten, Özlem/Tahir Gürçağlar, Şehnaz (eds.): Perspectives on Retranslation: Ideology, Paratexts, Methods. New York/London: Routledge, 87-103.

Ziemann, Zofia 2017a: The Good Bad Translator: Celina Wieniewska and Her Bruno Schulz. In Asymptote Blog, 20 Sept. [online]. https://www.asymptotejournal.com/blog/2017/09/20/the-good-bad-translator-celina-wieniewska-and-her-bruno-schulz/ (accessed 20 Oct. 2017).

Ziemann, Zofia 2017b: Translating Polish Jewishness: Bruno Schulz in English. In Translatologica: A Journal of Translation, Language, and Literature 1 [online]. http://www.ifa.uni.wroc.pl/translatologica/voll.html (accessed 20 Oct. 2017).

Ziemann, Zofia 2016: The Online Afterlife of a Polish Modernist Classic: John Curran Davis's Fan Translation of the Fiction of Bruno Schulz. In CTIS Occasional Papers 7 [online]. http://www.alc.manchester.ac.uk/ctis/research/ publications/ (accessed 5 June 2017).

Ziemann, Zofia 2014: The Inner and Outer Workings of Translation Reception: Coetzee on (Wieniewska's) Schulz. In Kucała, Bożena/Kusek, Robert (eds.): Travelling Texts: J.M. Coetzee and Other Writers. Frankfurt am Main/Bern/ Bruxelles: Peter Lang, 79-91. 